\title{
Investigation of the Effects of Alcohol-Based Fuel Additive on Engine Performance and Exhaust Emissions in a Spark-Ignition Gasoline Engine
}

\begin{abstract}
Suleyman Ustun ${ }^{1}$
0000-0001-8349-1236

${ }^{1}$ Automotive Programme, Akhisar Vocational School, Manisa Celal Bayar University, Manisa, 45100, Turkey

Abstract

Although fossil fuel reserves have been decreasing day by day, the high carbon emissions of fossil-based vehicles and the fact that these carbon emissions trigger global warming cause researchers to focus on alternative fuels. $\mathrm{CO}$ and $\mathrm{HC}$, which form the exhaust emissions of motor vehicles, called unburned fuel, have been, threatened human health. Efforts to reduce $\mathrm{CO}_{2}$, which triggers global warming, and $\mathrm{NO}_{\mathrm{x}}$ emissions, which turn into acid rain, are increasing day by day. It is tried to reduce harmful exhaust emissions by mixing ethanol, methanol, propanol, butanol and their derivatives fuels as alcohol-based fuels in motor fuels in certain proportions. The aim of this study is to investigate the usability of waste fusel oil and plant-based methanol as an alternative fuel in internal combustion engines without the need for any auxiliary system and investigate the effects of fusel oil and methanol fuels added to gasoline on engine performance and emissions. In the experimental study, as engine performance, it was determined that the engine torque decreased by $11.62 \%$ in F20 fuel and $6.45 \%$ in M20 fuel compared to G fuel.While an increase in BSFC values was detected in both test fuels, there was a decrease in EGT values.According to the emission results, an average decrease of $7.31 \%$ in $\mathrm{F} 20$ fuel and $13.40 \%$ in M20 fuel was detected in $\mathrm{CO}$ values compared to $\mathrm{G}$ fuel, while an increase in $\mathrm{CO}_{2}$ and $\mathrm{NO}_{\mathrm{x}}$ values occurred.
\end{abstract}

Keywords: Methanol ; Alternative fuels; Exhaust emissions ; Engine performance
Research Article

https://doi.org/10.30939/ijastech..1000603

$\begin{array}{ll}\text { Received } & 25.09 .2021 \\ \text { Revised } & 20.10 .2021 \\ \text { Accepted } & 22.10 .2021\end{array}$

* Corresponding author

Suleyman Ustun

suleyman.ustun@cbu.edu.tr

Address:Automotive Programme, Akhisar Vocational School, Manisa Celal Bayar University, Manisa,Turkey

Tel:+902364129531

\section{Introduction}

Many researches have been carried out around the world for suitable alternative fuel potentials that can replace fossil-based fuel resources with limited reserves in the future. In addition to meeting the fossil-based fuel characteristics of alternative fuels, pollutant exhaust emission values are expected to be low. Studies have shown that alcohol-based fuels give values close to fossil fuel properties and pollutant exhaust emissions are lower. In addition to the use of pure alcohol-based fuels, research continues within the framework of mixtures applied into fossil fuels at certain rates. Motor vehicle emissions have been a major risk in the last few decades in terms of global warming, noise and environmental pollution. In addition, although it is clearly understood that the exhaust emissions of motor vehicles, which are increasing day by day, threaten human health, it is almost impossible to reduce the number of vehicles due to their importance in daily life. Motor vehicle manufacturers are obliged to produce their vehicles within the scope of emission restrictions within the framework of international agreements. In many state management policies, there are strategic man- agement policies to reduce harmful emission values and reduce the carbon footprints of countries. In this context, emission reduction studies are becoming more important day by day and lead researchers to search for interesting alternatives [1,2]. Fusel oil is the waste liquid left over from the production of ethyl alcohol obtained from molasses formed after sugar beet production. Fusel oil contains many different types of alcohol. $[3,4,5]$. Fusel oil blended test fuels, which were put in $10 \%$, $20 \%$ and $30 \%$ gasoline by volume, were tested in a gasoline engine and the highest torque increase was obtained in 30\% fusel blended fuel. Specific fuel consumption at all engine speeds increased depending on the amount of fusel oil additive. The highest increase was obtained with F30 fuel as $7.7 \%$. Depending on the amount of fusel oil in the mixtures, nitrogen oxide $\left(\mathrm{NO}_{\mathrm{x}}\right)$ emissions decreased while hydrocarbon $(\mathrm{HC})$ and carbon monoxide (CO) emissions have been increased [6]. In the experimental study of Eyidogan et al., on the addition of ethanol and methanol to gasoline, it was determined that ethanol-gasoline and methanol-gasoline mixtures (E5, E10, M5 and M10) brake specific fuel consumption increased compared to 
gasoline, and there was a general decrease in $\mathrm{CO}, \mathrm{HC}, \mathrm{CO}_{2}$ and $\mathrm{NO}_{\mathrm{x}}$ emissions with the use of alcohol mixtures. Similar studies have been done also by Danaiah et al. $[7,8]$. Calam et al. compared the engine performance and emission characteristics of mixtures of Ethanol (E25), Methanol (M25), Fusel oil (F25), Naphtha (N25), isopropanol (IP25), Butanol (B25) and nheptane in an HCCI engine. In this study, it was determined that $\mathrm{CO}$ and $\mathrm{HC}$ values increased due to the amount of water contained in the fusel oil. The amount of water in fusel oil affects combustion and emissions. Purifying the amount of water in the fusel oil with sodium chloride improves the test results. Ethanol-Methanol fuel mixtures have been seen to increase engine performances (volumetric efficiency, torque and braking power) in general, and reduce pollutant emissions (carbon monoxide (CO) and unburned hydrocarbons (UHC) $[9,10,5]$. Methanol fuel is an alcohol-based fuel that can be mixed with gasoline at a lower mixing ratio and provides better performance in spark ignition engines. However, methanol poses problems, especially with regard to its energy content and vapor lock properties. Focusing on this subject, Sharudin et al. investigated engine performance and emission results by mixing 5-15\% isobutanol in methanol-gasoline mixtures (M5). It has been seen in an experimental study that M5B15 provides improvement in engine braking power, BTE (brake thermal efficiency) and EGT (exhaust gas temperature) compared to other blended fuels [11]. It has been revealed that fusel oil increases the octane number of the fuel, volumetric efficiency and engine torque in mixtures with gasoline, reduces knocking and nitrogen oxides $\left(\mathrm{NO}_{\mathrm{x}}\right)$, and affects engine performance depending on the amount of water it contains. There are also experimental studies done by mixing fusel oil into diesel fuel $[12,13]$. Şimşek et al., in their experimental study, performed experiments at constant speed and different ratios for six different fuel mixture ratios (F0, F10, F20, F30, F40 and F50) and compared with the original operating parameters of a gasoline engine. According to the test results, optimum engine performance was obtained with 9.12/1 compression ratio and F30 fuel mixture. It was found that by increasing the compression ratio from $8 / 1$ to $9-12 / 1$ for the F30 fuel mixture, the overall efficiency increased by $6.91 \%$ and the specific fuel consumption decreased by $2.35 \%$. In the effects of fusel oil on emissions, it was determined that $\mathrm{CO}$ emissions increased by $36.82 \%$, $\mathrm{HC}$ emissions by $23.07 \%, \mathrm{NO}_{\mathrm{x}}$ emissions by $15.42 \%$, and $\mathrm{CO}_{2}$ emissions by $13.88 \%$ [14]. Ehtasham et al., In their experimental study, they tested $0 \%, 3 \%, 6 \%, 9 \%, 12 \%$ methanol-gasoline mixtures in a four-stroke, single-cylinder SI engine and demonstrated their artificial neural network (ANN) assisted performance and emission analysis. In the study, it was observed that the continuous addition of methanol up to 12\% (M12) increased engine performance. However, a decrease was observed in emissions other than $\mathrm{NO}_{\mathrm{x}}$ emissions [15]. In his experimental study, Calam investigated the effects of fusel oil on combustion, performance and exhaust emissions in an HCCI engine at different lambda and inlet temperatures. In the use of prepared test fuels (n-heptane, F20, F40 and F60), it has been determined that fusel oil not having economic benefit, improves engine performance and emissions in HCCI engines under appropriate conditions. Similarly, Solmaz tested it in an HCCI engine by blending $37.5 \%$ fusel oil and $62.5 \% \mathrm{n}$ heptane (Fusel40) in his experimental study. It was determined that fusel oil had a better effect in reducing $\mathrm{CO}$ and $\mathrm{HC}$ emissions than increasing the compression ratio [16,17]. In his experimental study, Ozer, by mixing secondary fatty acids with $20 \%$ by volume of diesel fuel and adding alcohol (ethanol, methanol, isopropyl, n-butanol and fusel oil) at the same rate, on a single-cylinder, direct-injection diesel engine, combustion, fuel line pressure. investigated its effects on engine performance and exhaust emissions. According to the results of the study, it was determined that all fuel mixtures provided a decrease in $\mathrm{CO}$ and smoke opacity emissions and an increase in $\mathrm{HC}$ and $\mathrm{NO}_{\mathrm{x}}$ emissions. On the other hand, Fusel oil and high oil waste costs are very low compared to diesel fuel. The use of fusel oil as a fuel also provides an important advantage [18]. Balki et al. obtained M5, M10, M15 and M20 fuels by mixing methanol at $5 \%, 10 \%, 15 \%$ and $20 \%$ by volume, respectively. These test fuels were tested in a single-cylinder gasoline engine at two different loads (10 and $20 \mathrm{Nm})$ and at different compression ratios (CR), (7:1, 8:1, 9:1). When exhaust emissions are evaluated, it has been found that M20 is more suitable than gasoline when used in a small SI engine at 9:1 CR. [19]. Yaman et al., in their experimental study, n-pentanol was mixed in gasoline at $5 \%, 10 \%, 15 \%$ and $20 \%$ by volume, and tests were carried out on a single-cylinder gasoline engine, at a constant speed of $1600 \mathrm{rpm}$ and variable loads between $1-5 \mathrm{~kW}$, at $1 \mathrm{~kW}$ intervals. Findings from tests showed that infusion of n-pentanol into gasoline reduced $\mathrm{HC}, \mathrm{CO}, \mathrm{CO}_{2}$ and $\mathrm{NO}_{\mathrm{x}}$ emissions compared to basic gasoline, but higher $\mathrm{O}_{2}$ levels [20]. Örs et al. mixed $10 \%$ methanol and $10 \%$ ethanol into gasoline and compared it in terms of engine performance and emissions. In the study, the addition of methanol and ethanol showed similar combustion properties. Addition of methanol and ethanol to gasoline increased BSFC' Exhaust gas temperature (EGT), $\mathrm{CO}_{2}, \mathrm{NO}_{\mathrm{x}}$ and decreased $\mathrm{CO}$ and $\mathrm{HC}$ emissions. It has been stated that methanol and ethanol can be mixed with gasoline in certain proportions [21]. In the current experimental study by Puricelli et al, the Euro 6d-TEMP GDI passenger car was tested with four different fuels, both in the laboratory and on the road. Prepared test fuels Fuel B (bioethanol and bionaphtha), Fuel C (a high level of renewable ethers ) and Fuel D (methanol and bioethanol) gasoline fuel were compared with Fuel A. An increase in $\mathrm{NO}_{\mathrm{x}}$ amounts $(+48.1 \%)$ was detected in methanol blended fuel [22]. When the literature studies are reviewed, the interest in alcohol blended fuels is high.

In this study, in parallel with the literature studies, alcoholbased fuel mixtures were tested in a gasoline engine and the results were presented. Different from the literature studies, tests were carried out at different loads and speeds at the same mixing ratios. Test fuels prepared in experimental studies were mixed directly into gasoline by volume $20 \%$ methanol and 
$20 \%$ fusel oil without the need for any auxiliary system to the engine, and engine performance and emission values were compared with gasoline, which is a fossil-based fuel. $20 \%$ methanol and 20\% fusel oil by volume were mixed in gasoline and engine performance and emission values were compared with gasoline, which is a fossil-based fuel. The aim of this study is to investigate the usability of waste fusel oil and plantbased methanol as alternative fuels in internal combustion engines. One the the other hand, it is to reveal the effects on alternative fuel availability, engine performance and emission output efficiencies by reducing harmful exhaust emissions.

\section{Material and Method}

\subsection{Test Fuel Preparations}

In the experimental study, 95 octane unleaded gasoline fuel (G) and fusel oil and pure methanol produced on vegetable basis were used. By mixing 20\% Fusel oil (F20) and 20\% pure Methanol (M20) by volume into gasoline, engine performance (Torque, Brake Specific Fuel Consumption (BSFC), Exhaust gas temperature (EGT)) and Exhaust emissions, carbon monoxide $(\mathrm{CO})$, Carbon dioxide $\left(\mathrm{CO}_{2}\right)$ and Nitrous oxide $\left(\mathrm{NO}_{\mathrm{x}}\right)$ values were measured. Experimental studies were carried out under full load conditions of the engine and the data were instantly recorded on the computer. Table 1 gives the physical and chemical properties of Fusel oil.

Table 1. Fusel oil physical and chemical properties [14,3]

\begin{tabular}{|c|c|c|c|c|c|c|c|}
\hline 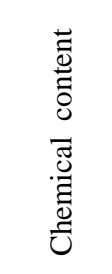 & 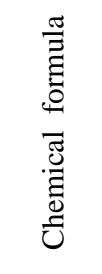 & 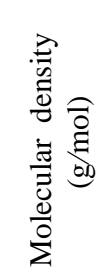 & 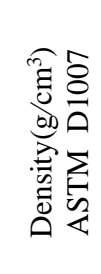 & 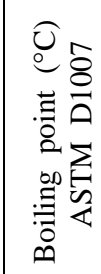 & 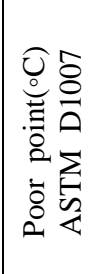 & 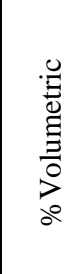 & 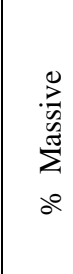 \\
\hline $\begin{array}{l}\text { i-amyl } \\
\text { alcohol }\end{array}$ & $\mathrm{C}_{5} \mathrm{H}_{12} \mathrm{O}$ & 88.148 & 0.8104 & 131.1 & -117.2 & 63.93 & 61.52 \\
\hline $\begin{array}{l}\text { i-butyl } \\
\text { alcohol }\end{array}$ & $\mathrm{C}_{4} \mathrm{H}_{10} \mathrm{O}$ & 74.122 & 0.802 & 108 & -108 & 16.66 & 15.87 \\
\hline $\begin{array}{l}\text { n-butyl } \\
\text { alcohol }\end{array}$ & $\mathrm{C}_{4} \mathrm{H}_{10} \mathrm{O}$ & 74.122 & 0.8098 & 117.73 & -89.5 & 0.736 & 0.708 \\
\hline $\begin{array}{l}\text { n-propyl } \\
\text { alcohol }\end{array}$ & $\mathrm{C}_{3} \mathrm{H}_{8} \mathrm{O}$ & 60.09 & 0.8034 & 97.1 & -126.5 & 0.738 & 0.704 \\
\hline Ethanol & $\mathrm{C}_{2} \mathrm{H}_{6} \mathrm{O}$ & 46.07 & 0.789 & 78.4 & -114 & 9.58 & 8.98 \\
\hline Water & $\mathrm{H}_{2} \mathrm{O}$ & 18 & 1 & 100 & 0 & 10.3 & 12.23 \\
\hline
\end{tabular}

The test fuels were mixed with a magnetic stirrer for 15 minutes in a graduated beaker at the rates of M20 (20\% methanol-80\% Gasoline) and F20 (20\% Fusel oil and 80\% Gasoline) by volume, and the mixture became homogeneous. Samples were taken from this prepared test fuel and its physical and chemical properties were determined within the framework of standard measurement methods. The physical and chemical properties of pure methanol, fusel oil and gasoline are given in Table 2.

Table 2. Physical and chemical properties of Methanol, Fusel oil and Gasoline[23-25,14].

\begin{tabular}{|c|c|c|c|}
\hline Properties & Methanol & Fusel oil & Gasoline \\
\hline Molecular weight & 32.04 & 74,122 & 91.4 \\
\hline $\begin{array}{c}\text { Lower Calorific } \\
\text { Value }(\mathrm{Mj} / \mathrm{kg})\end{array}$ & 20.10 & 29.514 & 42.9 \\
\hline RON/MON & $106 / 96$ & $103.61 / 106.82$ & $95 / 85$ \\
\hline $\begin{array}{c}\text { Density }\left(20^{\circ} \mathrm{C}^{\prime} \mathrm{de}\right) \\
(\mathrm{kg} / \mathrm{m} 3)\end{array}$ & 790 & 852.1 & $720,0-775,0$ \\
\hline Poor point $\left({ }^{\circ} \mathrm{C}\right)$ & $>50$ & $>50$ & -53 \\
\hline $\begin{array}{c}\text { Dynamic viscosity } \\
\left(20{ }^{\circ} \mathrm{C}\right)[\mathrm{mPas}]\end{array}$ & 0.57 & 2,278 & 1.2 \\
\hline
\end{tabular}

\subsection{Test Equipments}

Test equipments consists of test engine, exhaust emission device and engine dynamometer. The engine dynamometer is connected to the test engine by means of a coupling. The exhaust temperature sensor and the emission device exhaust probe are connected to the test engine exhaust. Dynamometer torque sensor, fuel gauge sensor, exhaust temperature sensor are connected to the dynamometer control module. Figure 1 shows the schematic picture of the experimental study.

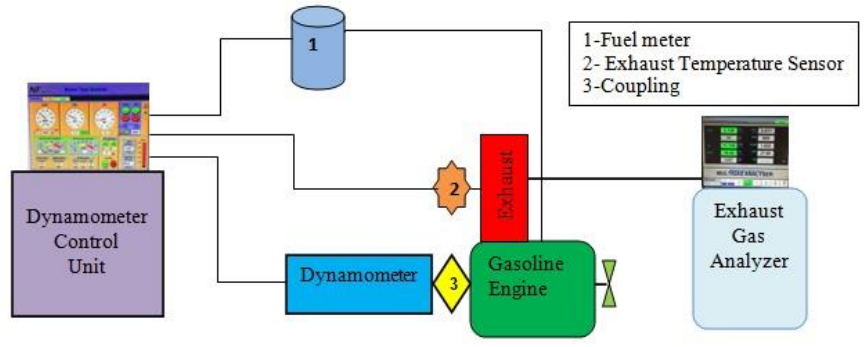

Fig. 1. Experimental study schematic picture

\subsubsection{Test Engine}

In the experimental studies, a single-cylinder, four-stroke atmospheric gasoline engine was used. The motor was combined with the coupling connection to the dynamometer. Periodic maintenance of the test engine was carried out before each measurement. The air filter was cleaned, the engine oil was checked, the fuel hose connections and the engine fixing connections were checked. The test engine was run at idle until it reached the regime temperature $\left(300{ }^{\circ} \mathrm{C}\right)$ and measurements were started after this temperature. The engine throttle was 
brought to the full throttle position and the test starting speed was determined as $3500 \mathrm{rpm}$. Engine performance and emission values were recorded to the computer as instant data at every $500 \mathrm{rpm}$ intervals. The maximum torque speed of the test engine is $2500 \mathrm{rpm}$, and the maximum power speed is 3400 $\mathrm{rpm}$. The test engine specifications are given in Table 3.

Table 3 Test engine specifications

\begin{tabular}{|c|c|}
\hline Engine Type & $\begin{array}{c}\text { Single cylinder }-4 \text { stroke }- \\
\text { Air Cooled }\end{array}$ \\
\hline Torque & $32 / 2500 \mathrm{Nm} / \mathrm{rpm}$ \\
\hline Piston Diameter x Stroke & $68 \times 54 \mathrm{~mm}$ \\
\hline Cylinder Volume & $196 \mathrm{cc}$ \\
\hline Compression Ratio & $8,5: 1$ \\
\hline $\begin{array}{c}\text { Maximum power }-\mathrm{HP} \\
(\mathrm{kW}) \text { @ rpm }\end{array}$ & $17(12.4) \quad 3400 \mathrm{rpm}$ \\
\hline
\end{tabular}

In the exhaust emission measurements, an emission device integrated with the computer was used. For gasoline vehicles, the device performs $\mathrm{CO}, \mathrm{CO}_{2}, \mathrm{HC}, \mathrm{O}_{2}$, Lambda and AFR measurements with a non-dispersive infrared system. In Table 4 , the technical specifications of the exhaust emission device are given.

Table 4. Properties of the exhaust gas analyzer

\begin{tabular}{|c|c|c|}
\hline Emission & Mesuring range & $\begin{array}{c}\text { Measurement } \\
\text { Accuracy }\end{array}$ \\
\hline $\mathrm{CO}$ & $0-\% 10$ & $\% 0,001$ \\
\hline $\mathrm{CO}_{2}$ & $0-\% 20$ & $\% 0,001$ \\
\hline $\mathrm{HC}$ & $0-10000$ & $1 \mathrm{ppm}$ \\
\hline $\mathrm{O}_{2}$ & $0-\% 25$ & $\% 0,01$ \\
\hline $\mathrm{CO}$ Corr & $0-\% 10$ & $\% 0,001$ \\
\hline $\mathrm{NO}_{\mathrm{x}}$ (OPS.) & $0-5000$ & $1 \mathrm{ppm}$ \\
\hline Lambda & $0,5-2.00$ & 0.001 \\
\hline AFR & $5-30$ & - \\
\hline $\begin{array}{c}\text { Engine Oil Temperature } \\
\text { (OPS.) }\end{array}$ & $0-150{ }^{\circ} \mathrm{C}$ & $1{ }^{\circ} \mathrm{C}$ \\
\hline RPM (OPS.) & $0-9990 \mathrm{rpm}$ & $10 \mathrm{rpm}$. \\
\hline Opacity & $\% 0-100$ & $\% 0,1$ \\
\hline
\end{tabular}

\subsubsection{Engine Dynamometer}

The test motor has been connected to the dynamometer by means of a coupling. It consists of dynamometer, fuel meter, dynamometer control module and control panel. Starting and stopping the test engine is done on the dynamometer control screen. After the engine has been started, it is operated at idle until it reaches the regime temperature. Engine exhaust gas temperature, engine speed, engine torque, engine power, hourly fuel consumption, specific fuel consumption are instantly seen and recorded on the dynamometer screen. After the engine reaches the regime temperature, full throttle is applied, and the engine is loaded from the dynamometer until the test start speed reaches $3500 \mathrm{rpm}$. The dynamometer reverse-loads the engine so that the engine speed drops at $25 \mathrm{rpm}$ with each command. When it reaches $3500 \mathrm{rpm}$, engine performance and exhaust emission values are recorded to the computer as instant data. Measurements were repeated every $500 \mathrm{rpm}$. Engine dynamometer specifications are given in Table 5.

Table 5. Engine dynamometer specifications

\begin{tabular}{l|l}
\hline Maximum braking power & $26 \mathrm{~kW}$ \\
\hline Maximum braking torque & $83 \mathrm{Nm}$ \\
\hline $\begin{array}{l}\text { Exhaust temperature } \\
\text { measuring range }\end{array}$ & $0-1000{ }^{\circ} \mathrm{C}$ (Thermocouple) \\
\hline Incremental Encoder & $0-8000 \mathrm{rpm}$ \\
\hline Operating voltage & $380 \mathrm{~V}, \mathrm{AC}$, \\
\hline Ambient temperature & $40^{\circ} \mathrm{C}$ \\
\hline Control unit & $\begin{array}{l}\text { Engine speed and load control, instan- } \\
\text { taneous speed, torque, power, hourly } \\
\text { fuel consumption, specific fuel con- } \\
\text { sumption, exhaust gas } \\
\text { temperature. }\end{array}$ \\
\hline
\end{tabular}

\section{Experiment Results and Discussion}

In this study, 20\% fusel oil (F20) and 20\% pure methanol (M20) by volume were added to 95 octane gasoline (G). Test fuels were tested in a single-cylinder atmospheric engine under full load conditions, and engine performance and exhaust emission values were compared with gasoline fuel.

\subsection{Engine performances}

Torque changes of test fuels are shown in Figure 2. At the maximum torque speed, G fuel produced $28.82 \mathrm{Nm}, \mathrm{F} 20$ fuel produced $26.72 \mathrm{Nm}$ and M20 fuel produced $27.55 \mathrm{Nm}$. On average, a torque decrease of $11.62 \%$ in F20 fuel and $6.45 \%$ in M20 fuel was determined. M20 fuel provided less torque drop than F20 fuel. The amount of water in the fusel oil is quite high and this affects the combustion performance [10]. When Table 2 is examined, although the lower calorific value of fusel oil is higher than that of methanol fuel, the torque reduction is higher than that of M20 fuel. The density of M20 fuel is lower than fusel oil. In addition, the viscosity of F20 fuel is higher than M20 fuel. This is thought to improve fuel atomization and combustion efficiency. When Table 1 is examined, there is a small amount of water in fusel oil. The water in the fuel worsens the combustion and lowers the end-of-combustion pressure. The lower performance of F20 fuel compared to M20 fuel can be shown as a reason for this situation. The amount of oxygen in alcohol-based fuels is higher than in fossil fuels. This affects the in-cylinder combustion performance. It can be thought that the excess oxygen in the fuel improves the engine performance by positively affecting the combustion in the cylinder. However, since the heating values, fuel densities and viscosities of M20 and F20 fuels are lower than G fuel, it causes the engine torque values to decrease. This situation has also been ob- 
served in similar studies in the literature [5,11,30-32].

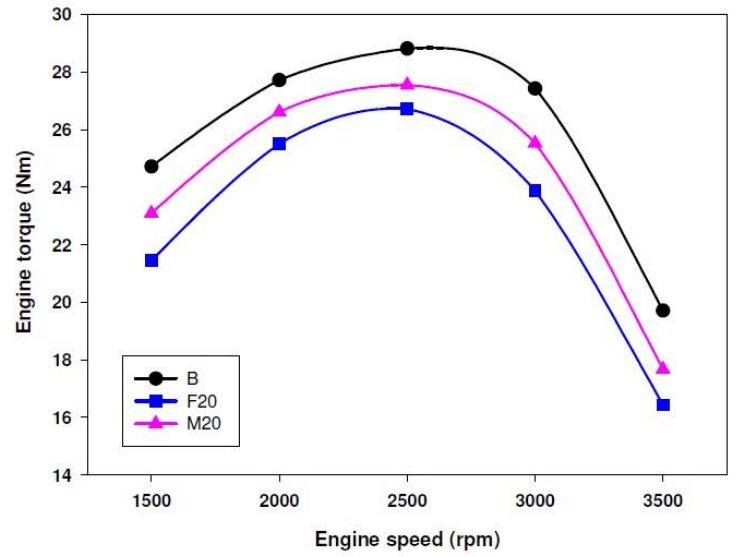

Fig.2. The effect of methanol and fusel oil addition in test fuels on engine torque

The brake specific fuel consumption of the test fuels is shown in Figure 3. Brake specific fuel consumption (BSFC) was measured as $362.08 \mathrm{~g} / \mathrm{kWh}$ in $\mathrm{G}$ fuel, $397.77 \mathrm{~g} / \mathrm{kWh}$ in F20 fuel and $374.34 \mathrm{~g} / \mathrm{kWh}$ in M20 fuel at maximum torque speed. Compared to gasoline, BSFC showed an increase in F20 and M20 fuels. This increase was found to be $9.79 \%$ in F20 fuel and $4.23 \%$ in M20 fuel on average. Heating value differences of fuels affect BSFC results [26,28]. Although the heating value of fusel oil is higher than that of methanol, the BSFC value of F20 fuel was higher than that of M20 fuel. The specific fuel consumption value is proportional to the calorific value of the fuels and their conversion to useful work in the cylinder [18]. The reason why the BSFC value of M20 fuel is lower than that of F20 fuel is due to the differences in the heating value as well as the different density and viscosity values of the fuels. Fusel oil worsens combustion and increases BSFC because it contains water. Uslu and Celik [29] stated that alcohol fuels have lower calorific values and higher stoichiometric fuel/air ratios compared to gasoline, so more fuel will be used to provide the same output power in SI engines, which will increase the BSFC. There are many studies showing that BSFC values increase in alcohol-based fuel usage due to low calorific value $[7,12,21,26]$.

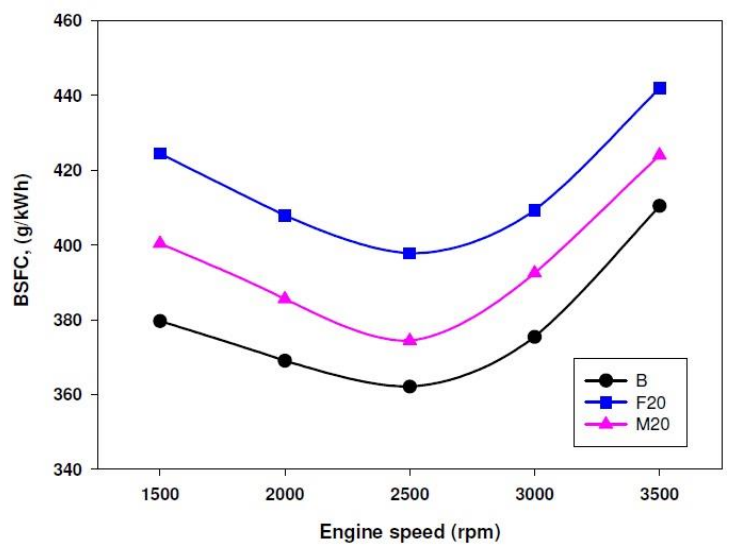

Fig.3. The effect of methanol and fusel oil addition in test fuels on
BSFC

Figure 4 shows the exhaust gas temperature (EGT) changes of the test fuels. At maximum torque speed, it was measured as $701.88{ }^{\circ} \mathrm{C}$ in $\mathrm{G}$ fuel, $681.19^{\circ} \mathrm{C}$ in $\mathrm{F} 20$ fuel and $658.20^{\circ} \mathrm{C}$ in M20 fuel. F20 and M20 EGT temperatures showed a decrease compared to $\mathrm{G}$ fuel. The highest EGT decrease occurred in M20 fuel. For all test fuels, maximum temperatures were obtained close to maximum power speed. At all engine speeds, on average, EGT decreased by $3.22 \%$ in F20 fuel and $5.91 \%$ in M20 fuel. The reason for the EGT decreases of F20 and M20 fuels compared to $\mathrm{G}$ fuel is that alcohol-based fuels have a higher latent heat of vaporization than $G$ fuel [7]. The high BSFCs of F20 and M20 test fuels were interpreted as the EGT temperatures decreased as a result of the increase in the amount of mixture taken into the cylinder to provide the same power. Sharudin et al., Alcohol-based fuels have higher latent heat of vaporization and lower heating value than Gasoline fuel, which reduces EGT. This situation has also been found in similar literature studies [12,13,16,20,27].

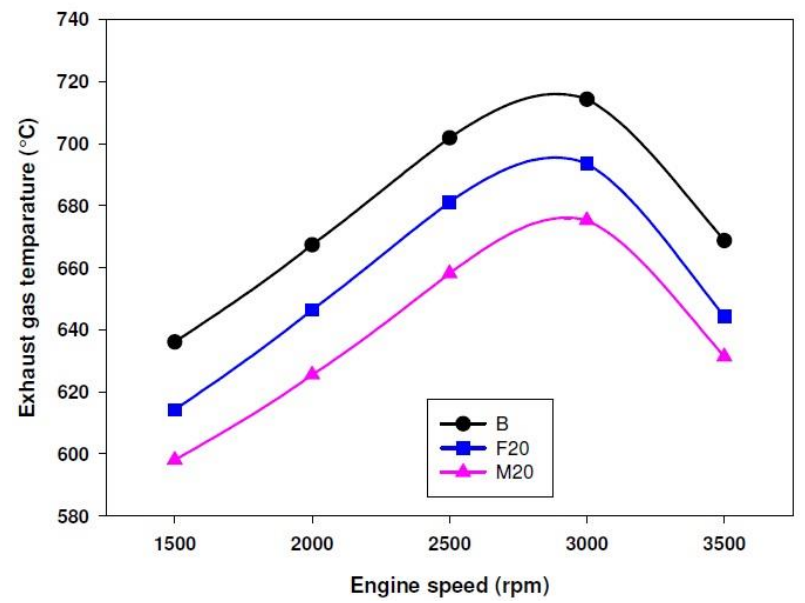

Fig.4. The effect of methanol and fusel oil addition in test fuels on EGT

\subsection{Exhaust emissions}

$\mathrm{CO}$ Carbon monoxide $(\mathrm{CO})$ changes of test fuels are shown in Figure 5. Compared to $\mathrm{G}$ fuel, $\mathrm{CO}$ emission values decreased in F20 and M20 fuels. At maximum torque speed, CO values were measured as $8.32 \%$ in $\mathrm{G}$ fuel, $7.78 \%$ in $\mathrm{F} 20$ fuel and 7.31 in M20 fuel. The highest $\mathrm{CO}$ reduction was achieved in M20 fuel. On average, $\mathrm{CO}$ values decreased by $7.31 \%$ in F20 fuel and $13.40 \%$ in M20 fuel at all engine speeds. Excess $\mathrm{CO}$ is a product of incomplete combustion. On the contrary, when full combustion is provided in the cylinder, the $\mathrm{CO}$ values decrease. The excess of oxygen in the content of alcoholbased fuels improves combustion compared to fossil fuels. This reduces the $\mathrm{CO}$ values [4,7,8]. The use of alcohol-based fuels reduces $\mathrm{CO}$ emissions. Due to the high oxygen content of alcohol-based fuels, the reason for the decrease in $\mathrm{CO}$ is complete combustion, especially at low rpm. The fact that M20 fuel further reduces the amount of $\mathrm{CO}$ compared to F20 fuel indicates that M20 fuel properties are better than F20 fuel. Da- 
ta on $\mathrm{CO}$ reduction and cause-effect relationships are consistent with previous studies [12-14,18-22]

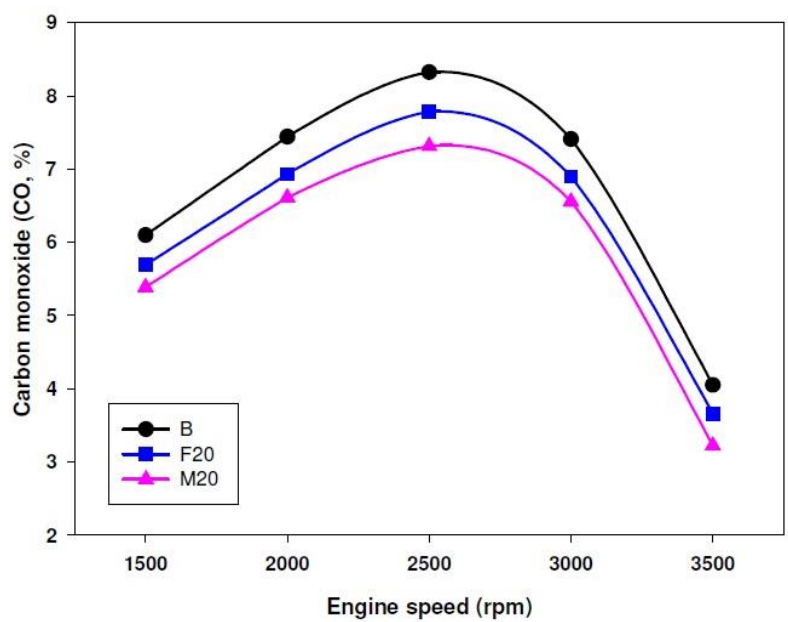

Fig.5. The effect of methanol and fusel oil addition in test fuels on $\mathrm{CO}$

Figure 6 shows the $\mathrm{CO}_{2}$ changes of the test fuels. The $\mathrm{CO}_{2}$ values of the test fuels increased compared to $\mathrm{G}$ fuel. On aveage, $\mathrm{CO}_{2}$ values increased at all engine speeds, $10.73 \%$ in F20 fuel and 5.90\% increase in M20 fuel. M20 fuel produced less $\mathrm{CO}_{2}$ than $\mathrm{F} 20$ fuel. An increase in carbon dioxide emissions is due to the effect of oxygen increases, which contributes to an increase in the rate of complete combustion. Increasing oxygen during combustion will result in more carbon that can be converted to carbon dioxide. Excess oxygen in alcoholbased fuels improves combustion. This affects the formation of $\mathrm{CO}_{2}$ [12]. Since fusel oil contains oxygen, the hydroxyl radical $\mathrm{OH}$ (one of the major oxidizing agents) converts carbon monoxide to carbon dioxide with the presence of sufficient oxygen $\mathrm{O}_{2}$ [14].. The fact that the amount of oxygen in fusel oil and methanol is higher than gasoline fuel affects combustion and it can be said that this situation causes an increase in $\mathrm{CO}_{2}$. Similar studies in the literature also refer to the high oxygen content of alcoholic fuels as the main reason for the increase in $\mathrm{CO}_{2}[18-22,26-30]$.

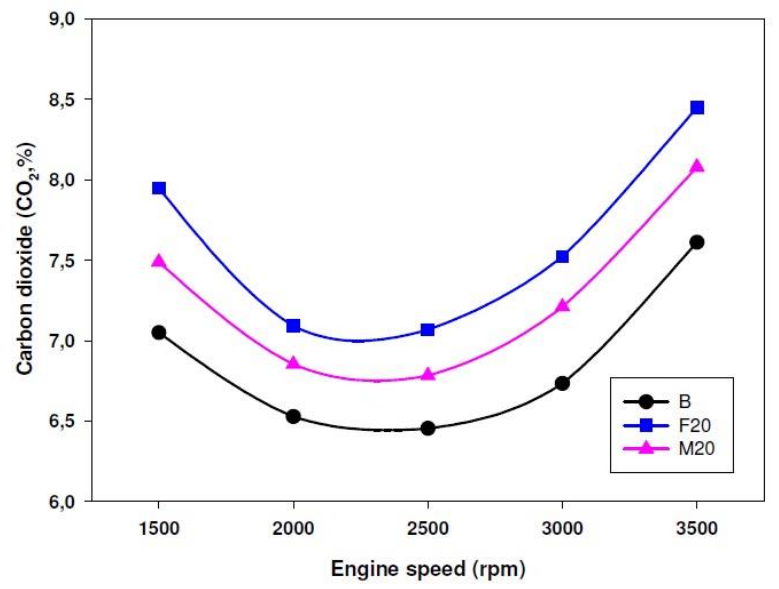

Fig.6. The effect of methanol and fusel oil addition in test fuels on$\mathrm{CO}_{2}$
Figure 7 shows the $\mathrm{NO}_{\mathrm{x}}$ changes of the test fuels. The $\mathrm{NO}_{\mathrm{x}}$ values of the test fuels increased compared to $\mathrm{G}$ fuel. F20 fuel produced more $\mathrm{NO}_{\mathrm{x}}$ than $\mathrm{M} 20$ fuel. On average, an increase of $12,62 \%$ in F20 fuel and $9.67 \%$ in M20 fuel was detected at all engine speeds compared to $\mathrm{G}$ fuel. $\mathrm{NO}_{\mathrm{x}}$ formation is an emission due to high temperatures resulting from combustion in the cylinder. At temperatures above $1500{ }^{\circ} \mathrm{C}, \mathrm{NO}_{\mathrm{x}}$ formation occurs [6,7]. Fusel oil and methanol are alcohol-based fuels. The high amount of oxygen in alcohol-based fuels affects the endof-combustion temperature and this increases the formation of $\mathrm{NO}_{\mathrm{x}}$. Looking at Figure 7, the reason why M20 fuel produces less $\mathrm{NO}_{\mathrm{x}}$ than $\mathrm{F} 20$ fuel may be due to the oxygen differences in the fuel. On the other hand, BSFC values of F20 and M20 fuels were higher than $\mathrm{G}$ fuel. The high BSFC causes an increase in $\mathrm{NO}_{\mathrm{x}}$ as a result of more fuel-air mixture being taken into the cylinder to provide the power corresponding to the unit volume and therefore the increase in the in-cylinder combustion end temperatures. Similar studies and similar results triggering $\mathrm{NO}_{x}$ increase were obtained by other researchers $[1,12,19,21,32]$.

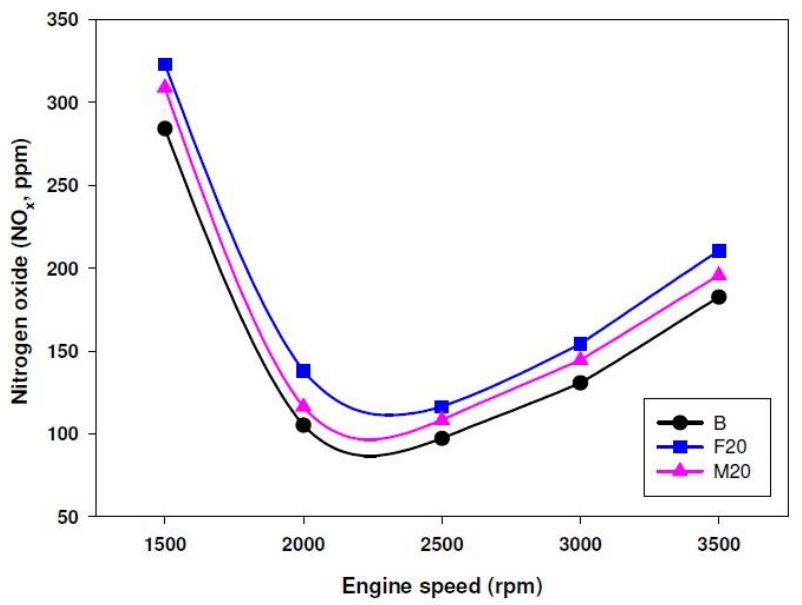

Fig.7. The effect of methanol and fusel oil addition in test fuels on $\mathrm{NO}_{\mathrm{x}}$

\section{Conclusions}

In this study, engine performance and exhaust emission values were measured by adding $20 \%$ fusel oil and $20 \%$ methanol into gasoline, which is a fossil-based fuel. As a result of the experimental study;

- Compared to G fuel, torque decreased in F20 and M20 test fuels.

- BSFC increased 9.79\% in F20 fuel and 4.23\% in M20 fuel compared to $\mathrm{G}$ fuel at all engine speeds,

- The EGT temperatures of the test fuels decreased on average by $3.22 \%$ in F20 fuel and $5.91 \%$ in M20 fuel.

- It was determined that $\mathrm{CO}$ values decreased by $7.31 \%$ in F20 fuel and $13.40 \%$ in M20 fuel,

- $\mathrm{CO}_{2}$ values increased by $10.73 \%$ in F20 fuel and $5.90 \%$ in M20 fuel,

- Compared to $\mathrm{NO}_{\mathrm{x}} \mathrm{G}$ fuel, it increased $12.62 \%$ in F20 fuel and $9.67 \%$ in M20 fuel. 
- M20 and F20 ratios can be used by mixing directly into gasoline without the need for any additional system to the engine system.

- Studies can be expanded with different mixing ratios and different fuels.

\section{Nomenclature}

$\begin{array}{ll}\text { M20 } & \begin{array}{l}\text { :Test fuel consisting of a mixture of } 20 \% \\ \text { Methanol- } 80 \% \text { gasoline by volume }\end{array} \\ \text { F20 } & \text { :Test fuel consisting of a mixture of } 20 \% \\ & \text { Fusel oil and } 80 \% \text { gasoline by volume } \\ \text { BSFC } & \text { :Brake Specific Fuel Consumption } \\ \mathrm{CO} & \text { :Carbon monoxide } \\ \mathrm{CO}_{2} & \text { :Carbon dioxide } \\ \mathrm{NO}_{\mathrm{x}} & \text { :Nitrogen oxide } \\ \mathrm{G} & \text { :Gasoline } \\ \mathrm{EGT} & \text { :Exhaust Gas Temperature } \\ \mathrm{RON} & \text { :Research Octane Number } \\ \mathrm{MON} & \text { :Engine Octane Number }\end{array}$

\section{References}

[1] Mishra PC, Gupta A, Kumar A, Bose A. Methanol and petrol blended alternate fuel for future sustainable engine: A performance and emission analysis. Measurement. 2020; 155:107519.

[2] Turnau S, Mignot CS, Mostert C, Bringezu S. Material or fuel: comparative cradle-to-grave climate and material footprint analysis for the use of methanol from recycled $\mathrm{CO}_{2}$. Green Chemistry. 2020; 22(23):8423-8443.

[3] Calam A, Icingur Y, Solmaz H, Yamik HA. Comparison of Engine Performance and the Emission of Fusel Oil and Gasoline Mixtures at Different Ignition Timings. Int J Green Energy. 2015; 12 (8):767-772.

[4] Simsek S, Saygin H, Ozdalyan B. Improvement of fusel oil features and effect of its use in different compression ratios for an SI engine on performance and emission. Energies. 2020; 13(7): 1824.

[5] Ustun, S. Investigation of engine performance and emission characteristics of organic-based manganese addition into waste fusel oil-diesel mixture. Journal of the Faculty of Engineering and Architecture of Gazi University. 2021; 36(3) :1516-1529.

[6] İcingur Y, Calam A. Fuzel Yağı Benzin Karışımlarının Buji İle Ateşlemeli Bir Motorda Performans ve Emisyonlara Etkisi. Journal of the Faculty of Engineering and Architecture of Gazi University. 2012; 27 (1):143-149.

[7] Eyidogan M, Canakcı M, Ozsezen AN, Alptekin E, Turkcan A, Kilicaslan İ. Etanol-Benzin ve Metanol-Benzin Karışımlarının Buji İle Ateşlemeli Bir Motorun Yanma Parametrelerine ve Egzoz Emisyonlarına Etkisinin İncelenmesi. Journal of the Faculty of Engineering and Architecture of Gazi University. 2011; 26 (3): 499-507.

[8] Danaiah P, Kumar PR, Kumar DV. Effect of methanol gasoline blended fuels on the performance and emissions of SI engine. International Journal of Ambient Energy. 2013; 34(4): 175180.

[9] Calam A, Aydogan, B, Halis S. The comparison of combustion, engine performance and emission characteristics of ethanol, methanol, fusel oil, butanol, isopropanol and naphtha with n-heptane blends on HCCI engine. Fuel. 2020; 266: 117071.
[10] Elfasakhany A. Performance and emissions of spark-ignition engine using ethanol-methanol-gasoline, n-butanol-iso-butanolgasoline and iso-butanol-ethanol-gasoline blends: a comparative study. Engineering science and technology, an international journal. 2016; 19(4): 2053-2059.

[11] Awad OI, Ali OM, Mamat R, Abdullah AA, Najafi G, Kamarulzaman MK et al. Using fusel oil as a blend in gasoline to improve SI engine efficiencies: A comprehensive review. Renew Sustain Energy Rev.2017; 69: 1232-1242.

[12] Sharudin H, Abdullah NR, Najafi G, Mamat R, Masjuki HH. Investigation of the effects of iso-butanol additives on spark ignition engine fuelled with methanol-gasoline blends. Appl Therm Eng. 2017; 114: 593-600.

[13] Agbulut U, Saridemir S, Karagoz M. Experimental nvestigation of fusel oil (isoamyl alcohol) and diesel blends in a CI engine. Fuel. 2020; 267:117042.

[14] Simsek S, Saygin H, Ozdalyan B. Improvement of fusel oil features and effect of its use in different compression ratios for an SI engine on performance and emission. Energies. 2020; 13(7):1824.

[15] Ahmed E, Usman M, Anwar S, Ahmad HM, Nasir MW, Malik MAI. Application of ANN to predict performance and emissions of SI engine using gasoline-methanol blends. Sci Prog. 2021 Jan-Mar;104(1):368504211002345.

[16]. Calam, A. Effects of the fusel oil usage in HCCI engine on combustion, performance and emission. Fuel, 2020; 262:116503.

[17]. Solmaz, H. A comparative study on the usage of fusel oil and reference fuels in an HCCI engine at different compression ratios. Fuel. 2020; 273:117775.

[18]. Özer S. The effect of diesel fuel-tall oil/ ethanol/ methanol/ isopropyl/n-butanol/fusel oil mixtures on engine performance and exhaust emissions. Fuel. 2020; 281:118671.

[19]. Balki MK, Temur M, Erdogan S, Sarıkaya M, Sayin C. The determination of the best operating parameters for a small SI engine fueled with methanol gasoline blends. Sustainable Materials and Technologies. 2021; 30: e00340).

[20]. Yaman H, Yesilyurt MK. The influence of n-pentanol blending with gasoline on performance, combustion, and emission behaviors of an SI engine. Engineering Science and Technology, an International Journal. 2021; 24 (6) :1329-1346.

[21]. Chauhan BV, Shukla MK, Dhar A. Effect of n-Butanol and Gasoline Blends on SI Engine Performance and Emissions. In Alcohol as an Alternative Fuel for Internal Combustion Engines. Singapore: Springer; 2020. pp. 175-190.

[22]. Puricelli S, Casadei S, Bellin T, Cernuschi S, Faedo D, Lonati $\mathrm{G}$, et al. The effects of innovative blends of petrol with renewable fuels on the exhaust emissions of a GDI Euro 6d-TEMP car. Fuel. 2021; 294:120483.

[23] Miganakallu N, Yang Z, Rogóż R, Kapusta Ł J, Christensen C, Barros $\mathrm{S}$ et al. Effect of water- methanol blends on engine performance at borderline knock conditions in gasoline direct injection engines. Applied Energy. 2020; 264:114750.

[24] Tüpraş Ürünler. $\quad$ Erişim 06.09 .2021 https://tprstaticfilessa.blob.core.windows.net/ assets/uploads/ urunler/Tpr_Yp_Usp_Kursunsuz_Benzin_0243.pdf

[25] Waluyo B, Setiyo M et al. Fuel performance for stable homogeneous gasoline-methanol-ethanol blends. Fuel. 2021;294: 120565.

[26] Celik MB, Ozdalyan B et al. The use of pure methanol as fuel at high compression ratio in a single cylinder gasoline engine. Fuel. 2011; 90(4): 1591-1598. 
[27] Ustun S. Determination of optimum manganese amount by response surface methodology with alcohol-gasoline fuel blend in an SI engine. Int J Environ Sci Technol. 2021;1-14.

[28] Dogan B, Yesilyurt MK, Dervis E et al. A study toward analyzing the energy, exergy and sustainability index based on performance and exhaust emission characteristics of a spark-ignition engine fuelled with the binary blends of gasoline and methanol or ethanol. Uluslararası Mühendislik Araştırma ve Geliştirme Dergisi. 2020; 12(2) :529-548.

[29] Paloboran M, Syam H et al. The Development of Combustion Strategy in Improving the Performances of SI-PFI Engine Using E50 of Gasoline-Bioethanol Fuel Blend. Вестник Московского государственного технического университета им. НЭ Баумана. Серия Естественные науки. 2021; (4) :115-135.

[30] Sivaprakasam P, Maheandera Prabu P, Srinivasan M, Balakrishnan S, Karthikeyan V S et al. Analysis of Ethanol to Reduce Solid Particle Pollution in SI Engines. J Nanomater._2021; (2021):1-11.

[31] Sarıkoc S. Effect of $\mathrm{H}_{2}$ addition to methanol-gasoline blend on an SI engine at various lambda values and engine loads: A case of performance, combustion, and emission characteristics. Fuel. 2021; 297:120732.

[32] Oxenham L, Wang Y. A Study of the Impact of Methanol, Ethanol and the Miller Cycle on a Gasoline Engine. Energies. 2021;14(16):4847. 